\title{
水平力を受ける鉄筋コンクリー STUDY ON THE RIGID ZONE OF 卜架構の剛域に関する研究 REINFORCED CONCRETE FRAMES UNDER HORIZONTAL LOADING
}

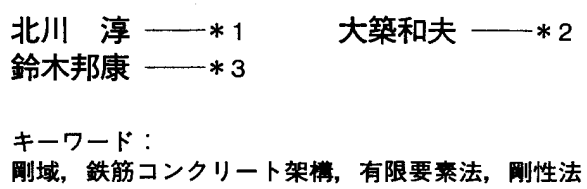

\section{Atsushi KITAGAWA - *1 \\ Kuniyasu SUZUKI $-* 3$ \\ Kazuo OTSUKI — $* 2$}

The purpose of this paper is to clarify the rigid zone lengths for reinforced concrete members. The rigid zone lengths were calculated from the results of finite element analysis of beam-column members. The equations to estimate the rigid zone lengths were derived to utilize those rigid zone lengths. The estimated rigid zone lengths were applied to the 3-spans 9-stories reinforced concrete frame, and those frames were analyzed by stiffness method. The results of the analysis were very much in agreement with the results of finite element analysis of those frames.
1.はじめに

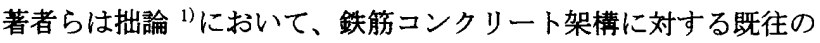
忍力及び変形解法の精度について、二次元有限要素法解析値との比 較により検討した。その結果、部材伸縮及び剛域を考虑しない解法 では大きな誤差を招く場合があること、曲げ・せん断・部材伸縮及 びR C 剛域 ${ }^{2)}$ を考感した剛性法による解析値が最も有限要素法解析 值に近似すること等を明らかにした。また、上記の剛性法によって も変位に関しては最上階あるいは最下階で、応力に関しては一部で 有限要素法解析值に近似しない部分が見られ、これらは剛域算定法 を変えることにより改善される可能性のあることも指摘した。

$\mathrm{R}$ C 剛域長さは、奥田氏の研究 ${ }^{3}$ に基づくものであり、柱、梁に 関係なく、単にその部材とそれに接続する部材のせいによって決め るとしている。しかし、剛域長さは応力状態によっても変わり ${ }^{4)} 、$ 更に、その部材の幅とその材に接続する部材のそれとの関係、ある いは接続部材の状況によっても変わると考えられる。また、 R C 剛 域算定法は手計算を前提とし、簡便さを第一としているが、構造解 析手段が手計算からコンピューターへと移行した今日、その算定法 が多少複雑であっても、構造物の解析精度を向上させるものであれ ば、十分有用であると考えられる。

このような視点に立ち、本論では剛域を取り入れて線材置換され る構造物の解析精度を高めることを目的として、柱梁からなるモデ ルを三次元有限要素法解析し、その結果に基づいて簡易な剛域算定 式を提示する。さらに、平面架構について二次元有限要素法及び剛 域を取り入れた剛性法による解析を行い、両者の比較により提案式
による剛域長さの適合性について検証する。なお、本論は既に建築 学会大会 ${ }^{5)}$ 及び建築学会北海道支部研究報告集 ${ }^{6)}$ に発表したものを 取りまとめ加筆したものである。

\section{2. 三次元有限要素法解析モデル及び解析法}

\section{1 解析モデル}

剛域算定のための解析モデルは、図ー 1 に示すような 4 タイプの 形状のもので、それぞれ（a ）は架構中間部の柱、（b）は同外側の 柱、（c）は中間階の梁、（d）は最上階または最下階の梁を想定し たものである。以下では、図示の垂直部分を単に「部材」、水平部分 を「直交部材」と呼び、図示の記号を用いる。

解析モデルの種別を表-1に示す。同表の部材断面のものについ て、部材の両側に直交部材がある場合と片側のみにそれがある場合 の 2 通りを考え、基本材長を $420 \mathrm{~cm}$ とした。柱を対象としたモデル （部材幅が直交部材幅よりも大きいもの）のうち部材断面 $60 \mathrm{~cm} \times$ $60 \mathrm{~cm}$ 、直交部材断面 $40 \mathrm{~cm} \times 80 \mathrm{~cm}$ のモデル*1 については、材長を $240 \mathrm{~cm}$, $300 \mathrm{~cm} ， 360 \mathrm{~cm}, 420 \mathrm{~cm}$ の 4 種に、梁を対象としたモデル（部材幅が 直交部材幅よりも小さいもの）のうち部材断面 $40 \mathrm{~cm} \times 80 \mathrm{~cm}$ 、直交部 材断面 $60 \mathrm{~cm} \times 60 \mathrm{~cm}$ のモデル*2については、材長を $310 \mathrm{~cm}, 420 \mathrm{~cm}$, $600 \mathrm{~cm}, 780 \mathrm{~cm}, 870 \mathrm{~cm}$ の 5 種に変化させた。材長を変化させたのは、 材長と剛域長さとの関係を調べるためであり、材長は通常ありうる 篔囲のものを適当に選んだ。なお、上記の他に後述の剛域算定に用 いるために、それぞれの断面の部材のみのものについて、材長 $\ell$ を 数種に変化させた場合についても解析した。

\footnotetext{
*1 室蘭工業大学建設システム工学科 研究生・博士(工学)

( 050-8585 室蘭市水元町27-1)

*2 室蘭工業大学建設システム工学科 教授・工博

*3 室蘭工業大学建設システム工学科 助手・工修
}

\footnotetext{
1 Research Worker, Dept. of Civil Eng. and Architecture, Muroran Institute of Technology, Dr. Eng.

*2 Prof., Dept. of Civil Eng. and Architecture, Muroran Institute of Technology, Dr. Eng.

*3 Research Assoc., Dept. of Civil Eng. and Architecture, Mruoran Institute of Technology, M. Eng.
} 


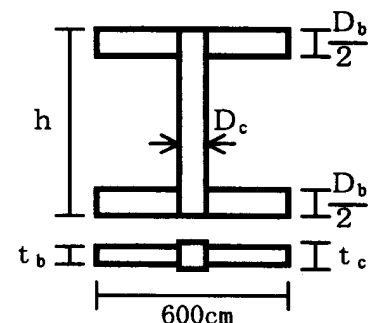

(a)

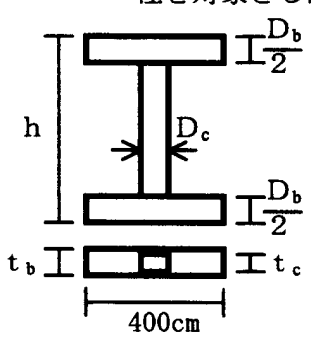

(c)

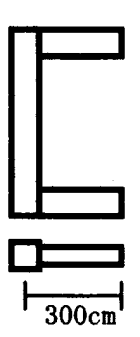

(b)

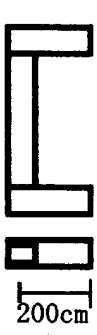

(d)

梁を対象としたもの

図一 1 解析モデルの形状

\section{2 解析方法}

解析は三次元有限要素法で行い、材端間に単位の水平変位差（単 位の層間変位）を与えた場合と材端に単位の回転角を与えた場合に ついて行った。解析に用いた単位要素は、要素内でひずみが線形変 化する自由度 24 の直方体要素である。要素分割の一例として図ー 2 に柱を対象とした部材断面 $60 \mathrm{~cm} \times 60 \mathrm{~cm}$ 、直交部材断面 $40 \mathrm{~cm} \times 60 \mathrm{~cm}$ 、 材長 $420 \mathrm{~cm}$ のモデルを示す。 $\mathrm{x}$ 方向分割は $10 \mathrm{~cm}, 12.5 \mathrm{~cm}, 15 \mathrm{~cm}, 12.5 \mathrm{~cm}$, $10 \mathrm{~cm}$ の 5 分割、y 方向分割は片側梁部分が $40 \mathrm{~cm} \times 1,30 \mathrm{~cm} \times 4,20 \mathrm{~cm}$ $\times 2,15 \mathrm{~cm} \times 2,10 \mathrm{~cm} \times 4$ の 13 分割、柱部分が全て $10 \mathrm{~cm}$ の 6 分割、 $\mathrm{z}$ 方向分割は全て $10 \mathrm{~cm}$ の 42 分割とした。その他の諸元のモデルも このモデルに準じた分割とした。

解析に際して、単位の層間変位を与える場合は、図一 2 に示す梁 材軸を通る $\mathrm{A}-\mathrm{A}$ 平面、 $\mathrm{B}-\mathrm{B}$ 平面内の全節点の $\mathrm{z}$ 方向変位及び $\mathrm{B}$ - $\mathrm{B}$ 平面内の全節点の $\mathrm{y}$ 方向変位を拘束し、 $\mathrm{x}$ 方向への移動を止め るために $\mathrm{B}-\mathrm{B}$ 平面内の $\mathrm{D}$ 点の $\mathrm{x}$ 方向変位を拘束した。外力として、 $\mathrm{A}-\mathrm{A}$ 平面内の全節点の $\mathrm{y}$ 方向に単位の変位 $\delta=1$ を与えた。

単位の回転角を与える場合は、支持条件として、図一 2 に示す梁 材軸を通る $\mathrm{B}-\mathrm{B}$ 平面内の全節点の $\mathrm{z}$ 方向変位、 $\mathrm{C}-\mathrm{C}$ 線上の $\mathrm{y}$ 方 向変位及びD点の $\mathrm{x}$ 方向変位を 0 とし、その他の節点は自由とした。 外力条件として、 $\mathrm{A}-\mathrm{A}$ 平面内の全節点の $\mathrm{z}$ 方向に、その面が平面 を保持したまま単位の回転角 $\theta=1$ となるように変位を与えた。

なお、ここでは上下対称という条件で、上下の梁とも梁せいの $1 / 2$ 位置で平面を保つとして解いている。これは、前者では反曲点が部 材の中央にあり、後者では部材全長に渡って曲げモーメント一定で あることを意味する。即ち、ここでの解析条件は、実構造物の部材 応力は両者の中間にあると考えて設定されたものである。

\section{3. 有限要素法解析結果に基つく同城長さ算定式の䋆等}

\section{1 网域長さ算定方法}

（1）単位層間変位時

表一 1 解析モデルの種別

\begin{tabular}{|c|c|c|}
\hline $\begin{array}{r}\text { 部材所面 } \\
\mathrm{t}_{\mathrm{c}} \times \mathrm{D}_{\mathrm{c}} \\
{[\mathrm{cm} \times \mathrm{cm}]}\end{array}$ & $\begin{array}{c}\text { 直交部材䤄面 } \\
t_{b} \times D_{b} \\
{[\mathrm{~cm} \times \mathrm{cm}]} \\
\end{array}$ & $\begin{array}{c}\text { 材長 } \\
\ell \\
{[\mathrm{cm}]}\end{array}$ \\
\hline $20 \times 45$ & $45 \times 60,50 \times 80$ & \multirow{14}{*}{$\begin{array}{l}420 \\
\text { 但し、 } \\
* * 1: 240,300,360,420 \\
* * 2: 310,420,600,780,870\end{array}$} \\
\hline $20 \times 60$ & $45 \times 80$ & \\
\hline $20 \times 80$ & $\begin{array}{l}20 \times 45,40 \times 45,45 \times 45 \\
35 \times 60,45 \times 60,50 \times 60\end{array}$ & \\
\hline $30 \times 60$ & $45 \times 45,60 \times 60,80 \times 80$ & \\
\hline $30 \times 80$ & $45 \times 45,60 \times 60,80 \times 80$ & \\
\hline $40 \times 45$ & $\begin{array}{c}20 \times 80,50 \times 80,60 \times 80 \\
70 \times 80,80 \times 80\end{array}$ & \\
\hline $40 \times 60$ & $\begin{aligned} 45 \times 45,60 \times 60 \\
50 \times 80,60 \times 80,70 \times 80,80 \times 80\end{aligned}$ & \\
\hline $40 \times 80$ & $\begin{array}{c}45 \times 45,80 \times 80 \\
30 \times 60,40 \times 60,60 \times 60^{* * 2} \\
30 \times 100,40 \times 100,50 \times 100,60 \times 100 \\
70 \times 100,80 \times 100,90 \times 100,100 \times 100\end{array}$ & \\
\hline $40 \times 100$ & $50 \times 100,70 \times 100,90 \times 100$ & \\
\hline $45 \times 45$ & $30 \times 60,30 \times 80,40 \times 60,40 \times 80$ & \\
\hline $45 \times 60$ & $30 \times 60,30 \times 80,40 \times 60,40 \times 80$ & \\
\hline $60 \times 45$ & $\begin{array}{l}30 \times 45,40 \times 45,60 \times 45 \\
30 \times 60,40 \times 60,60 \times 60\end{array}$ & \\
\hline $60 \times 60$ & $\begin{array}{l}30 \times 60,30 \times 80,30 \times 100 \\
40 \times 60,40 \times 80^{* * 1}, 40 \times 100\end{array}$ & \\
\hline $80 \times 80$ & $\begin{array}{l}30 \times 60,30 \times 80,30 \times 100 \\
40 \times 60,40 \times 80,40 \times 100\end{array}$ & \\
\hline
\end{tabular}

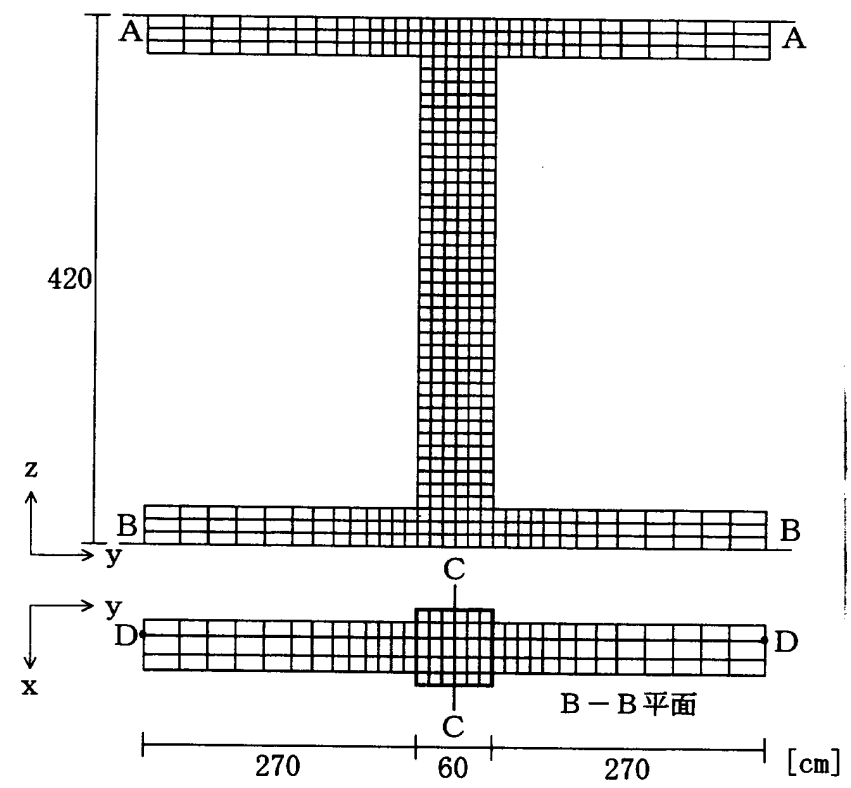

（部材断面 $60 \mathrm{~cm} \times 60 \mathrm{~cm}$ 、直交部材断面 $40 \mathrm{~cm} \times 60 \mathrm{~cm}$ )

图-2 要素分割の一例

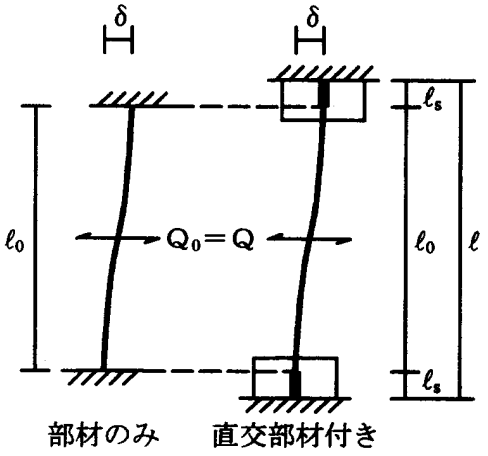

(a ) 単位の層間変位

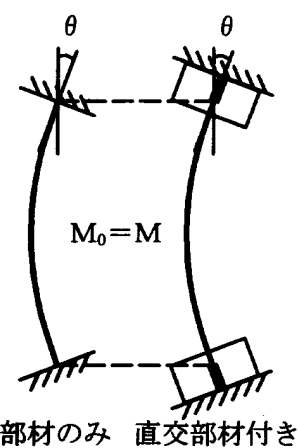

(b) 単位の回転角

图一３剛域算定の概念 
図ー3（a）に示すように、単位の層間変位を与えたときの直交 部材付き部材のせん断力 $\mathrm{Q}$ と部材のみのせん断力 $\mathrm{Q}_{0}$ が等しくなる ときの両者の材長の差から蒯城長さ $\ell_{s}$ を (1) 式のように算定する。

$$
\ell_{\mathrm{s}}=\frac{\ell-\ell_{0}}{2}
$$

この場合、部材のみのせん断力Q。は以下のように求める。

曲げ及びせん断変形を考虑した梁理論によれば、せん断力 $Q_{0}$ と変 位 $\delta$ との関係は (2) 式のようになる。

$$
\begin{aligned}
\delta & =\left(\frac{\ell^{3}}{12 \mathrm{E} \mathrm{I}}+\frac{\kappa \ell}{\mathrm{G} \mathrm{A}}\right) Q_{0} \\
こ こ に 、 \mathrm{E} & : \text { ヤング保数 }(=1.0) \\
\mathrm{I} & : \text { 断面 } 2 \text { 次モーメント } \\
\mathrm{A} & : \text { 断面積 } \\
\kappa & : \text { 形状係数 }(=1.2) \\
\mathrm{G} & : \text { せん断弾性係数 }(=\mathrm{E} / 2(1+v)) \\
\nu & : \text { ポアソン比 }(=1 / 6)
\end{aligned}
$$

ここで、 $\delta=1$ とし、上記の値を代入すると、単位層間変位時の 部材のみの場合の負担せん断力 $Q_{0}$ と材長 $\ell$ との関係は (3) 式の ような 3 次式になる。

$$
\frac{1}{\mathrm{Q}_{0}}=\left(\frac{\ell^{3}}{12 \mathrm{I}}+\frac{2.8 \ell}{\mathrm{A}}\right) \frac{1}{\mathrm{E}}
$$

しかし、（3）式の值と直交部材のない部材のみの有限要素法解析 結果を比較すると、両者の近似度合いは要素分割によって変化する。 従って、（3）式によって得られる $\mathrm{Q}_{0}$ を剛域長さ算定に用いること はその精度を悪くする。そこで、剛域算定に際しては部材のみの場 合のF EM解析結果に基ついて、 $Q_{0}$ と $\ell$ との関係を（4）式のよ うな 3 次式で近似させるとして各柱断面毎に係数 a , b , c ，d 最小 2 乗法により求め、その式により求まる $Q_{0}$ を使用した。ここで

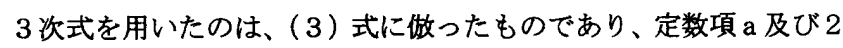
次の項を加えたのは近似式の精度を高めるためである。

$$
\frac{1}{\mathrm{Q}_{0}}=\mathrm{a}+\mathrm{b} \ell+\mathrm{c} \ell^{2}+\mathrm{d} \ell^{3}
$$

このようにすることにより、部材のみの場合と直交部材付きの場 合の分割状態はほぼ同様なので算定結果（剛域長さ）に及ぼす要素 分割の影響は微小となる。

(2) 単位回転角時

図ー3（b）に示すように単位の回転角を与えたときの直交部材 付き部材のモーメントMと部材のみのモーメント $\mathrm{M}_{0}$ が等しくなる ときの両者の材長の差から剛域長さ $\ell_{\mathrm{s}}$ を先の（1）式のように算定 する。

この場合、部材のみの場合の曲げモーメント $\mathrm{M}_{0}$ は以下のように求 める。

梁理論によれば材端に単位の回転角を与えたときのモーメントと 材長 $\ell_{0}$ との関係は（5）式のようになる。

$$
\mathrm{M}_{0}=\frac{2 \mathrm{EI}\left(2 \theta_{\mathrm{A}}+\theta_{\mathrm{B}}\right)}{\ell_{0}}
$$

ここで、 $\theta_{\mathrm{A}}=\theta_{\mathrm{B}}=1$ とすると、 $1 / \mathrm{M}_{0}=\ell_{0} / 6 \mathrm{E} \mathrm{I}$ となり、理 論的には $\mathrm{M}_{0}$ は $\ell_{0}$ に比例することになる。しかし、F EM解析值で は分割数などの関係で必ずしもそのようにはならない。
そこで、材長 $\ell_{0}$ とモーメント $\mathrm{M}_{0}$ の関倸を（6）式のような 1 次 式で近似させるものとする。（6）式の a は、先の場合と同様に近似 式の精度を高めるために加えたものである。

$$
\frac{1}{\mathrm{M}_{0}}=\mathrm{a}+\mathrm{b} \ell_{0}
$$

以下、単位層間変位時と同様に最小 2 乗法により部材のみの場合 のFEM解析值を処理して倸数 $\mathrm{a}$ ， b を求めた。

\section{2 剛域長さの比較}

表ー 2 は、前述の手法により F E M解析結果に基づいて求めた剛 域長さ（以下、FEM剛域と言う）及び既往の算定式（RC規準に 掲げられている式）による剛域長さ（以下、RC刪域と言う）を示 したものである。

（1）材長と剛域長さの関係

材長を変化させたモデル（部材断面 $60 \mathrm{~cm} \times 60 \mathrm{~cm}$ ，直交部材断面 $40 \mathrm{~cm} \times 80 \mathrm{~cm}$ 及び部材断面 $40 \mathrm{~cm} \times 80 \mathrm{~cm}$ ，直交部材断面 $60 \mathrm{~cm} \times 60 \mathrm{~cm})$ のF EM剛域について、材長と剛域長さの関係を見ると、各条件 (応 力状態、部材断面、直交部材の有無) 毎にそれらの差は $0.0 \mathrm{~cm} \sim 0.7 \mathrm{~cm}$ と極めて小さい。表には示していないがその他の断面のものについ ても同様であった。

したがって、材長の違いによる剛域長さの変化は大きくないので、 以降では材長 $420 \mathrm{~cm}$ の場合についてのみ検討する。

（2）応力状態と剛域長さの関係

直交部材が両側にあるモデルのF E M 剛域について、単位の回転 角を与えた場合と単位の層間変位を与えた場合の剛域長さを比較す ると、両者の差は $0.5 \mathrm{~cm} \sim 3.0 \mathrm{~cm}$ の範囲にある。実際の建築物での応 力状態は両者の中間的なものと考えられるので、用域長さも両者の 中間の值になると考えられる。

このように、応力状態の違いによる剛域長さの変化はそれほど大 きくないので、以降では単位の層間変位を与えた場合についてのみ 検討する。

（3）部材断面の形状と剛域長さの関係

F E M剛域とR C 剛域について、部材断面あるいは直交部材断面 の綎横比（ $\mathrm{D}_{\mathrm{c}} / \mathrm{t}_{\mathrm{c}}$ ）が違うモデルの剛域長さを比較すると、F E M剛域では、部材断面あるいは直交部材断面の紩横比が変化するに 伴い剛域長さも変化しているが、 R C 剛域では、剛域長さは一定と なっている。例えば、部材断面が同一で直交部材断面の繸横比が異 なるモデル（部材断面 $20 \mathrm{~cm} \times 80 \mathrm{~cm}$, 直交部材断面 $40 \mathrm{~cm} \times 45 \mathrm{~cm}, 45 \mathrm{~cm}$ $\times 45 \mathrm{~cm}$ ）について見ると、縋横比の違いにより F E M剛域と R C 剛 域の剛域長さの差が $10 \mathrm{~cm}$ 以上となるものも見られる。

したがって、 R C 骊域は部材のせいと直交部材のせいのみによっ て算出されているが、部材断面あるいは直交部材断面のせいのみで はなく幅も剛域長さに影響する要因として考える必要があると言え る。

(4) 直交部材の有無と剛域長さの関係

F EM剛域について、直交部材が両側にある場合と片側のみにあ る場合を比較すると、両者の差は $2.5 \mathrm{~cm} \sim 9.8 \mathrm{~cm}$ となり、直交部材断 面の違いにより両者の関係が異なることがわかる。これに対して、 R C 剛域では、直交部材が両側、片側に拘らず剛域長さは一定とな る。F E M剛域と R C 剛域を比較すると、直交部材が片側のみにあ る場合のR C 剛域は、F E M 剛域より $20 \mathrm{~cm}$ 近く大きくなるもの（部 
衰一 2 咧域長さ

\begin{tabular}{|c|c|c|c|c|c|c|c|c|}
\hline \multirow{3}{*}{$\begin{array}{c}\text { 部材断面 } \\
t_{\mathrm{c}} \times \mathrm{D}_{\mathrm{c}} \\
{[\mathrm{cm} \times \mathrm{cm}]}\end{array}$} & \multirow{3}{*}{$\begin{array}{c}\text { 直交部材 } \\
\text { 断面 } \\
t_{B} \times D_{B} \\
{[\mathrm{~cm} \times \mathrm{cm}]}\end{array}$} & \multirow{3}{*}{$\begin{array}{l}\text { 材長 } \\
{[\mathrm{cm}]}\end{array}$} & \multicolumn{6}{|c|}{ 剽域長さ $[\mathrm{cm}]$} \\
\hline & & & & ) & & (b) & 工丂 & \\
\hline & & & 回転角 & 屬閒 & 提案 & $\begin{array}{l}\text { 層間 } \\
\text { 変位 }\end{array}$ & 提案 & $\begin{array}{l}R \\
\text { 規 } \\
Y\end{array}$ \\
\hline $60 \times$ & $40 \times 80$ & $\begin{array}{l}240 \\
300 \\
360 \\
420 \\
\end{array}$ & $\begin{array}{l}18.9 \\
18.9 \\
18.9 \\
18.9 \\
\end{array}$ & $\begin{array}{l}21.0 \\
20.8 \\
20.6 \\
20.5 \\
\end{array}$ & \begin{tabular}{|l|}
20.5 \\
20.5 \\
20.5 \\
20.5 \\
\end{tabular} & \begin{tabular}{|l|}
13.4 \\
13.4 \\
13.4 \\
13.3 \\
\end{tabular} & \begin{tabular}{|l|}
13.4 \\
13.4 \\
13.4 \\
13.4 \\
\end{tabular} & $\begin{array}{l}25.0 \\
25.0 \\
25.0 \\
25.0 \\
\end{array}$ \\
\hline $40 \times 80$ & $60 \times 60$ & \begin{tabular}{|l|}
310 \\
420 \\
600 \\
780 \\
870 \\
\end{tabular} & \begin{tabular}{|l|}
15.6 \\
15.6 \\
15.5 \\
15.5 \\
15.6 \\
015
\end{tabular} & \begin{tabular}{|l|}
17.1 \\
16.8 \\
16.6 \\
16.5 \\
16.4 \\
\end{tabular} & \begin{tabular}{|l|}
16.6 \\
16.6 \\
16.6 \\
16.6 \\
16.6 \\
\end{tabular} & \begin{tabular}{|l|}
12.5 \\
12.5 \\
12.4 \\
12.4 \\
12.3 \\
\end{tabular} & \begin{tabular}{|l|}
12.3 \\
12.3 \\
12.3 \\
12.3 \\
12.3 \\
\end{tabular} & $\begin{array}{l}10.0 \\
10.0 \\
10.0 \\
10.0 \\
10.0 \\
\end{array}$ \\
\hline $20 \times 45$ & $\begin{array}{l}45 \times 80 \\
50 \times 80 \\
\end{array}$ & $\begin{array}{l}420 \\
420 \\
\end{array}$ & $\begin{array}{l}31.5 \\
31.5 \\
\end{array}$ & \begin{tabular}{|l|}
31.7 \\
31.7 \\
\end{tabular} & \begin{tabular}{|l|}
31.4 \\
31.9 \\
\end{tabular} & \begin{tabular}{|l|}
27.4 \\
27.5 \\
\end{tabular} & \begin{tabular}{|l|}
26.6 \\
27.4 \\
\end{tabular} & \begin{tabular}{|l|}
28.8 \\
28.8 \\
\end{tabular} \\
\hline $0 \times 60$ & $45 \times 80$ & 420 & 29.5 & 30.0 & 29.0 & 25.4 & 23. & \\
\hline $20 \times$ & $\begin{array}{r}* 20 \times 45 \\
* 40 \times 45 \\
* 45 \times 45 \\
35 \times 60 \\
45 \times 60 \\
50 \times 60 \\
\end{array}$ & $\begin{array}{l}420 \\
420 \\
420 \\
420 \\
420 \\
420 \\
\end{array}$ & $\begin{array}{r}6.9 \\
12.4 \\
12.7 \\
17.7 \\
18.8 \\
18.9 \\
\end{array}$ & $\begin{array}{r}8.6 \\
13.1 \\
13.4 \\
18.7 \\
19.7 \\
19.7 \\
\end{array}$ & \begin{tabular}{|r|}
9.5 \\
14.0 \\
14.6 \\
17.7 \\
19.4 \\
20.1 \\
\end{tabular} & \begin{tabular}{|r|}
4.8 \\
10.6 \\
10.9 \\
15.0 \\
16.3 \\
16.4 \\
\end{tabular} & $\begin{array}{r}6.5 \\
11.6 \\
12.3 \\
13.6 \\
15.7 \\
16.6 \\
\end{array}$ & $\begin{array}{r}2.5 \\
2.5 \\
2.5 \\
10.0 \\
10.0 \\
10.0 \\
\end{array}$ \\
\hline $30 \times 60$ & $\begin{array}{l}45 \times 45 \\
60 \times 60 \\
80 \times 80 \\
\end{array}$ & $\begin{array}{l}420 \\
420 \\
420 \\
\end{array}$ & $\begin{array}{l}11.9 \\
18.9 \\
28.5 \\
\end{array}$ & \begin{tabular}{|l|}
12.7 \\
19.6 \\
29.0 \\
\end{tabular} & \begin{tabular}{|l|}
12.5 \\
19.7 \\
30.0 \\
\end{tabular} & $\begin{array}{r}9.4 \\
15.5 \\
24.2 \\
\end{array}$ & $\begin{array}{r}9.2 \\
15.5 \\
25.1 \\
\end{array}$ & $\begin{array}{r}7.5 \\
15.0 \\
25.0 \\
\end{array}$ \\
\hline $30 \times 80$ & $\begin{array}{r}* 45 \times 45 \\
60 \times 60 \\
80 \times 80 \\
\end{array}$ & $\begin{array}{l}420 \\
420 \\
420 \\
\end{array}$ & $\begin{array}{l}10.5 \\
17.0 \\
26.2 \\
\end{array}$ & $\begin{array}{l}11.5 \\
18.0 \\
27.2 \\
\end{array}$ & \begin{tabular}{|l|}
11.7 \\
18.6 \\
28.4 \\
\end{tabular} & $\begin{array}{r}8.5 \\
14.2 \\
22.4 \\
\end{array}$ & $\begin{array}{r}8.7 \\
14.7 \\
23.5 \\
\end{array}$ & $\begin{array}{r}2.5 \\
10.0 \\
20.0\end{array}$ \\
\hline $40 x$ & & $\begin{array}{l}420 \\
420 \\
420 \\
420 \\
420 \\
\end{array}$ & \begin{tabular}{|l|}
20.7 \\
28.2 \\
29.1 \\
29.4 \\
29.6 \\
\end{tabular} & $\begin{array}{l}21.7 \\
28.8 \\
29.6 \\
29.8 \\
30.0 \\
\end{array}$ & $\begin{array}{l}21.9 \\
28.1 \\
29.2 \\
30.0 \\
30.8\end{array}$ & \begin{tabular}{|l|}
14.9 \\
22.4 \\
23.8 \\
24.4 \\
24.8 \\
\end{tabular} & & $\begin{array}{l}28.8 \\
28.8 \\
28.8 \\
28.8 \\
28.8\end{array}$ \\
\hline $40 \times 60$ & & \begin{tabular}{l|}
420 \\
420 \\
420 \\
420 \\
420 \\
420 \\
\end{tabular} & \begin{tabular}{|l|}
10.1 \\
17.7 \\
25.2 \\
26.4 \\
27.1 \\
27.2 \\
\end{tabular} & $\begin{array}{l}11.2 \\
18.6 \\
26.2 \\
27.2 \\
27.8 \\
27.9 \\
\end{array}$ & $\begin{array}{l}10.9 \\
18.0 \\
25.1 \\
26.4 \\
27.4 \\
28.3 \\
\end{array}$ & \begin{tabular}{|l|}
7.3 \\
13.9 \\
19.5 \\
21.2 \\
22.1 \\
22.4 \\
\end{tabular} & $\begin{array}{r}7.5 \\
13.4 \\
18.6\end{array}$ & $\begin{array}{r}7.5 \\
15.0 \\
25.0 \\
25.0 \\
25.0 \\
25.0\end{array}$ \\
\hline & $\begin{array}{r}8 \\
3 \\
40 \\
60 \\
30 \\
40 \\
50 \\
60 \\
70 \\
80 \\
90 \\
100 \\
\end{array}$ & $\begin{array}{l}420 \\
420 \\
420 \\
420 \\
420 \\
420 \\
420 \\
420 \\
420 \\
420 \\
420 \\
420 \\
420 \\
\end{array}$ & $\begin{array}{r}8.4 \\
24.5 \\
9.7 \\
11.3 \\
15.6 \\
23.4 \\
26.1 \\
29.1 \\
32.1 \\
32.7 \\
33.4 \\
33.7 \\
33.8 \\
\end{array}$ & $\begin{array}{r}9.8 \\
25.7\end{array}$ & $\begin{array}{l}10.0 \\
26.3\end{array}$ & $\begin{array}{r}6.3 \\
20.2 \\
6.8 \\
7.9 \\
12.5 \\
16.7 \\
18.8\end{array}$ & $\begin{array}{r}7.2 \\
9.2 \\
12.3 \\
17.0\end{array}$ & \begin{tabular}{|r|}
20.5 \\
20.0 \\
10.0 \\
10.0 \\
10.0 \\
30.0 \\
30.0 \\
30.0 \\
30.0 \\
30.0 \\
30.0 \\
30.0 \\
30.0
\end{tabular} \\
\hline 40 & & $\begin{array}{l}420 \\
420 \\
420 \\
\end{array}$ & $\begin{array}{l}27.0 \\
30.3 \\
31.3 \\
\end{array}$ & & & $\begin{array}{l}21.1 \\
25.2 \\
26.6\end{array}$ & & $\begin{array}{l}25.0 \\
25.0 \\
25.0\end{array}$ \\
\hline 45 & & $\begin{array}{l}420 \\
420 \\
420\end{array}$ & $\begin{array}{l}14.5 \\
22.9 \\
16.5 \\
25.2 \\
\end{array}$ & & & & & $\begin{array}{l}18.8 \\
28.8\end{array}$ \\
\hline 45 & & $\begin{array}{l}420 \\
420 \\
\end{array}$ & $\begin{array}{l}11.7 \\
19.0 \\
13.6 \\
21.4 \\
\end{array}$ & & & $\begin{array}{r}10.1 \\
8.0 \\
13.4 \\
9.3 \\
15.3\end{array}$ & $\begin{array}{r}8.0 \\
13.4 \\
9.8 \\
15.7\end{array}$ & \begin{tabular}{|l|}
20.0 \\
15.0 \\
25.0 \\
15.0 \\
25.0
\end{tabular} \\
\hline 6 & & \begin{tabular}{l|}
420 \\
420 \\
420 \\
420 \\
420
\end{tabular} & $\begin{array}{r}7.1 \\
8.7 \\
10.8 \\
12.4 \\
14.4 \\
17.2 \\
\end{array}$ & $\begin{array}{r}8.2 \\
9.7 \\
11.7\end{array}$ & 8 & $\begin{array}{l}4.7 \\
5.8 \\
7.3 \\
8.4 \\
9.9\end{array}$ & \begin{tabular}{|r|}
4.8 \\
6.0 \\
7.9 \\
8.4 \\
10.0
\end{tabular} & 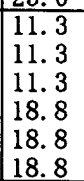 \\
\hline $60 \times$ & & $\begin{array}{l}420 \\
420 \\
420 \\
420 \\
420 \\
420 \\
\end{array}$ & $\begin{array}{r}9.8 \\
16.4 \\
- \\
11.6 \\
18.9 \\
- \\
\end{array}$ & $\begin{array}{l}11.2 \\
18.0 \\
25.8 \\
13.1 \\
20.5 \\
28.7 \\
\end{array}$ & $\begin{array}{l}11.2 \\
18.3 \\
26.4\end{array}$ & \begin{tabular}{|r}
6.7 \\
11.4 \\
17.3 \\
8.0 \\
13.3 \\
19.8 \\
\end{tabular} & $\begin{array}{r}1 . .4 \\
6.4 \\
11.3 \\
17.2 \\
8.0 \\
13.4 \\
20.0\end{array}$ & $\begin{array}{l}10.0 \\
15.0 \\
25.0 \\
35.0 \\
15.0 \\
25.0 \\
35.0\end{array}$ \\
\hline & & \begin{tabular}{l|}
420 \\
420 \\
420 \\
420 \\
490
\end{tabular} & $\begin{array}{r}5.8 \\
10.3 \\
15.9 \\
7.2 \\
12.4 \\
18.8\end{array}$ & $\begin{array}{r}7.5 \\
12.4 \\
18.3 \\
9.1 \\
14.7\end{array}$ & $\begin{array}{r}7.5 \\
12.7 \\
19.2 \\
9.1 \\
14.9 \\
21.9\end{array}$ & $\begin{array}{r}4.1 \\
7.1 \\
11.0 \\
5.1 \\
8.6 \\
19\end{array}$ & $\begin{array}{r}3.8 \\
6.8 \\
10.9 \\
5.0 \\
8.6 \\
19\end{array}$ & $\begin{array}{l}10.0 \\
20.0 \\
30.0 \\
10.0 \\
20.0 \\
30.0\end{array}$ \\
\hline
\end{tabular}

*算定式の誘導には使用せず
材断面 $80 \mathrm{~cm} \times 80 \mathrm{~cm}$ ，直交部材断面 $30 \mathrm{~cm} \times 100 \mathrm{~cm} ）$ も見られる。

以上のことより、R C 剛域は部材の接繶状慜を考虑せずに算出さ れているが、直交部材の接綂状㥿により刚域長さ算出方法を変える 必要があると考えられる。

以上のように、既往の剛域算定式では部材断面の形状、直交部材 の有無によって精度に変動が見られ、必ずしも十分とは言えない。

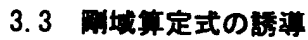

前述のF EM解析結果を整理して䣓域算定式を学く。前述のよう に材長及び応力状態の制域長さに及ぼす影签は小さいので、ここで は剛域長さ $\ell_{s}$ に影響する要因から除き、部材断面（部材幅 $\mathrm{t}_{\mathrm{a}}$ 、部材 せい $\mathrm{D}_{\mathrm{a}}$ 、直交部材幅 $\mathrm{t}_{\mathrm{b}}$ 及び直交部材せい $\mathrm{D}_{\mathrm{b}}$ ) 及び直交部材の有無 を考虑して剛域長さ算定式を導くことにする。この場合材長は $420 \mathrm{~cm}$ 、忘力状態はせん断力及びモーメントが作用した場合（単位層 間変位時）の值を用いることにする。また、㣚域算定式に汎用性を 与えるため、（7）式のように剛域長さ及び部材寸法を無次元化した 変数を用いることにする。

$$
\ell_{\mathrm{s}}^{\prime}=\frac{2 \ell_{\mathrm{s}}}{\mathrm{D}_{\mathrm{b}}}, \quad \mathrm{t}_{\mathrm{bc}}=\frac{\mathrm{t}_{\mathrm{b}}}{\mathrm{t}_{\mathrm{c}}}, \quad \mathrm{D}_{\mathrm{bc}}=\frac{\mathrm{D}_{\mathrm{b}}}{\mathrm{D}_{\mathrm{c}}}, \quad \mathrm{D}_{\mathrm{cc}}=\frac{\mathrm{t}_{\mathrm{c}}}{\mathrm{D}_{\mathrm{c}}}
$$

図ー 4 は綐軸に $\ell_{s}^{\prime}$ の值、横軸に $\mathrm{t}_{\mathrm{bc}}$ の值を取り、 $\mathrm{D}_{\mathrm{bc}}$ の值をパラ メーターとしてプロットした一例である。同図には、 $\mathrm{D}_{\mathrm{tc}}$ の值が異 なるものもプロットした。同図によると、他の值が同一なら $\mathrm{D}_{\mathfrak{c}}$ の 值が変わっても $\ell_{\mathrm{s}}^{\prime}$ と $\mathrm{D}_{\mathrm{bc}}$ の関俰は差程変わらない。そこで、 $\mathrm{D}_{\mathfrak{c}}$ の 值も㓮域長さの影響要因から除外し、剛域推定式を導くことにする。

$\mathrm{D}_{\mathrm{bc}}$ 毎に $\ell_{\mathrm{s}}^{\prime}$ と $\mathrm{t}_{\mathrm{bc}}$ の関保を (8) 式で近似させる。この式は $\mathrm{t}_{\mathrm{b}}$ が薄くなれば $\ell_{\mathrm{s}}^{\prime}$ は 0 に近づき、逆に厚くなれば 1 に近つくと考えた ものである。

$$
\ell_{s}^{\prime}=1-\frac{1}{1+\mathrm{a} \mathrm{t}_{\mathrm{bc}}^{\mathrm{b}}}
$$

F EM解析結果より $\mathrm{D}_{\mathrm{bc}}$ の値毎に（8）式の俰数 $\mathrm{a} ， \mathrm{~b}$ を最小 2 乗法で求めた。図一 5 は縦軸に $\mathrm{a}, \mathrm{b}$ の値を取り、横軸に $\mathrm{D}_{\mathrm{bc}}$ の值 を取ったものである。 $\mathrm{a}$ 及び $\mathrm{b}$ と $\mathrm{D}_{\mathrm{bc}}$ の関係を 2 次式で近似させ、 (9)，（10）式を得た。

\section{両側に直交部材がある場合}

$$
\left.\begin{array}{l}
\mathrm{a}=0.554+0.075 \mathrm{D}_{\mathrm{bc}}+0.421 \mathrm{D}_{\mathrm{bc}}{ }^{2} \\
\mathrm{~b}=1.572-1.078 \mathrm{D}_{\mathrm{bc}}+0.323 \mathrm{D}_{\mathrm{bc}}{ }^{2}
\end{array}\right\}
$$

片側のみに直交部材がある場合

$$
\left.\begin{array}{l}
\mathrm{a}=0.402-0.157 \mathrm{D}_{\mathrm{bc}}+0.283 \mathrm{D}_{\mathrm{bc}}^{2} \\
\mathrm{~b}=1.620-0.892 \mathrm{D}_{\mathrm{bc}}+0.220 \mathrm{D}_{\mathrm{bc}}{ }^{2}
\end{array}\right\}
$$

F EM棡域と（8）〜（10）式の提案式を用いて算定した剛域長 さ（以下、提案剛域と言う）を表一 2 の提案式の桐に揭げた。表に は提案式を導くのに用いなかったモデル（表中*印のもの）も揭げ た。因みに、F E M剛域との差について全モデルの平均值及び標準 偏差を求めると、それらの值は提案㣚域同側で-0.04 cm 及び $0.56 \mathrm{~cm}$ 、 同片側で $-0.06 \mathrm{~cm}$ 及び $0.64 \mathrm{~cm} 、 \mathrm{R} \mathrm{C}$ 㣚域 (雨側との比較で) $1.18 \mathrm{~cm}$ 及び $5.34 \mathrm{~cm}$ 、同 (片側との比較で) $-4.40 \mathrm{~cm}$ 及び $6.46 \mathrm{~cm}$ となり、 提案式はR C 剛域と比べて F E M 剛域との近似度は良く、推定式と しては十分な精度であると言える。また、本論文での解析モデルは 通常用いられている部材断面の簀囲を包含しており、実用式として 十分対応し得ると考えられる。 

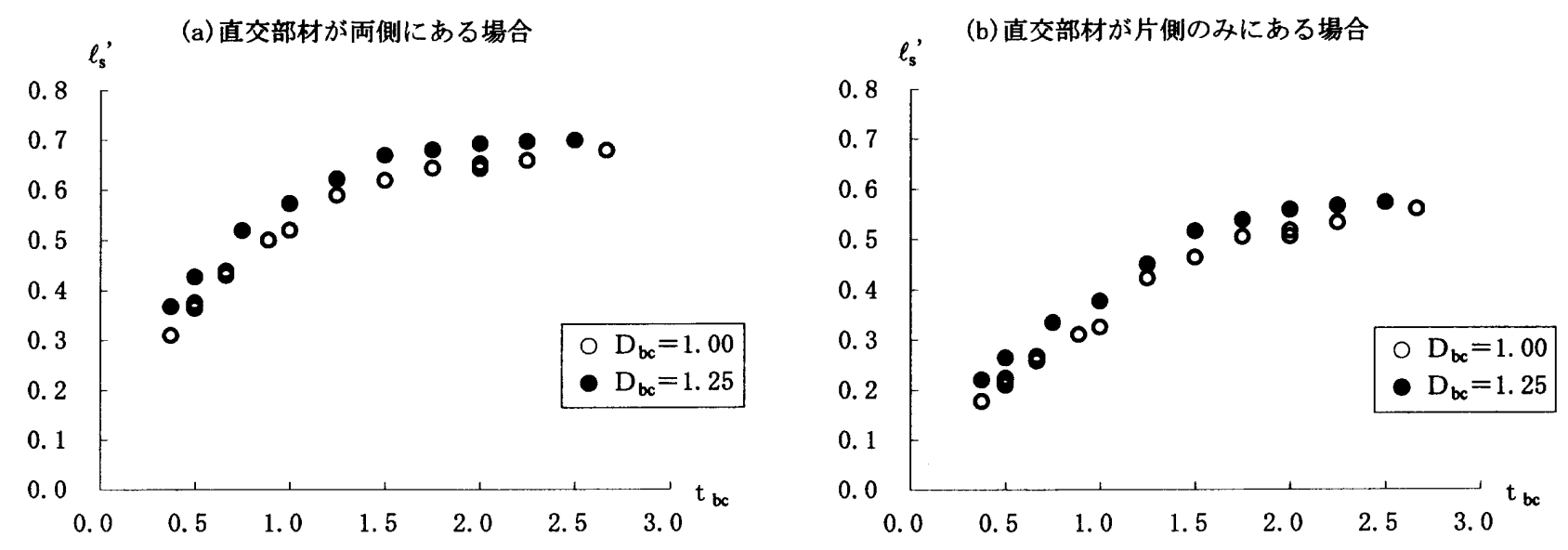

図-4 $\ell_{s}^{\prime}$ と $\mathrm{t}_{\mathrm{bc}}$ の関係の一例

a （a）直交部材が両側にある場合

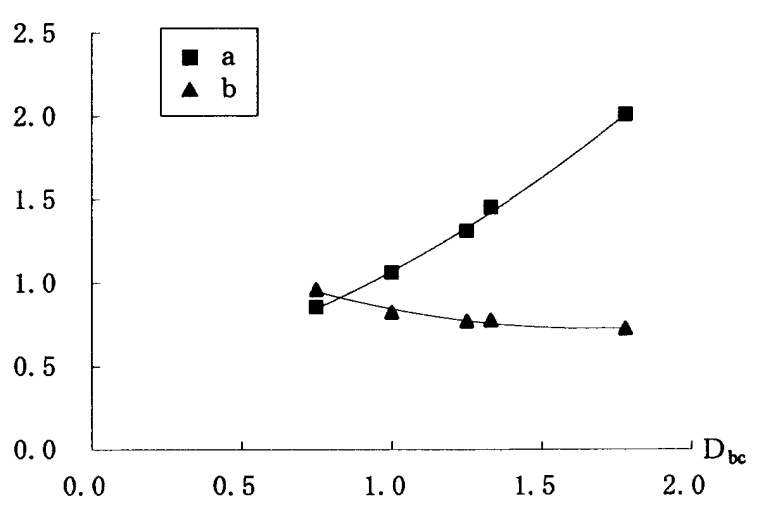

(b) 直交部材が片側のみにある場合

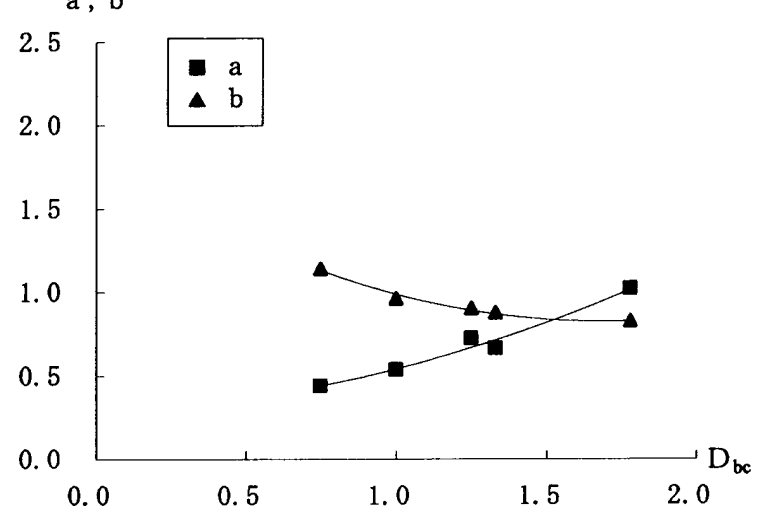

図一 $5 \quad \mathrm{a}, \mathrm{b}$ と $\mathrm{D}_{\mathrm{bc}}$ の関係

\section{4. 架栱モデルへの道用}

\section{1 解析モデル及び解析方法}

解析モデルは 3 スパン 9 層の平面架構で、図一 6 にその 3 階部分 までを示す。各部材の諸元は、スパン長 $600 \mathrm{~cm}$ 、階高 $360 \mathrm{~cm}$ 、柱断面 $55 \mathrm{~cm} \times 55 \mathrm{~cm}$ 、梁断面 $36 \mathrm{~cm} \times 75 \mathrm{~cm}$ （基礎梁断面 $36 \mathrm{~cm} \times 80 \mathrm{~cm} ）$ である。

平面架構の解析は二次元有限要素法及び曲げ ・ せん断・部材伸縮 及び材端剛域を考虑した線材モデルによる剛性法（以下、単に剛性 法と言う) で行った。有限要素法解析では、要素内でひずみが線形 に変化する自由度 8 の長方形要素を用い、表一 3 に示すような要素 分割とした。㣚性法では、材端にR C 剛域または提案棡域を取り入 れた。

解析に際して、1 階柱脚を固定とし、各階に単位の水平力 $\mathrm{P}=1$ を作用させ、ヤング係数 $\mathrm{Eを}$ 単位とし、コンクリートのポアソン数 を $1 / 6$ とした。なお、精解值として取り扱う二次元有限要素法解 析值（以下、FEM值と言う）の精度については拙論 ${ }^{1)}$ で検討して いる。

\section{2 有限要素法解析僆と网性法解析值との比较}

表ー 4 は層間変位及び柱端モーメントについて、F EM値とそれ に対する剛性法解析値の比を示したものである。

(1) 層間変位について

層間変位について見ると、 R C 刪域を取り入れた場合には階位置 によって $5 \%$ 程度比の値が変動しているが、提案剛域を取り入れた

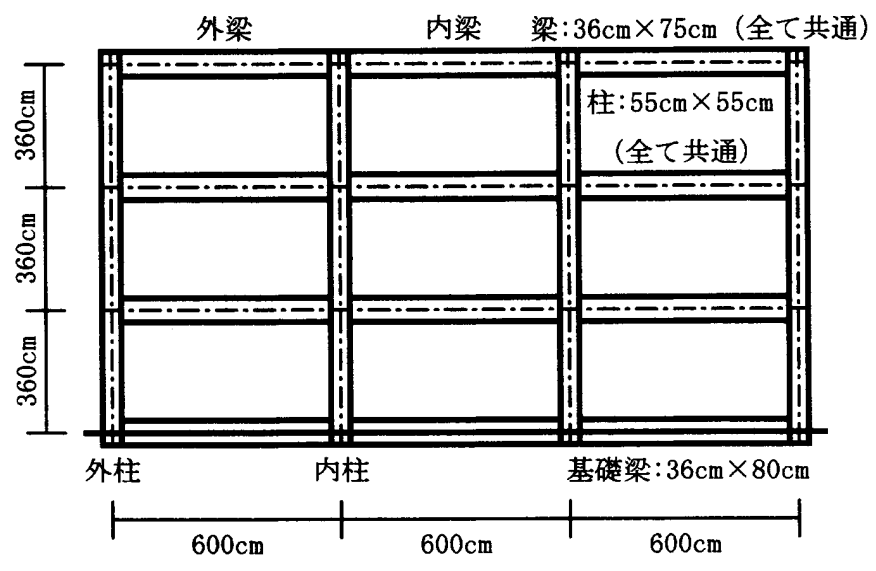

図ー6 平面架構の解析モデル（3 層部分）

表-3 要素分割状態 (分割長さ $[\mathrm{cm}] \times$ 分割数 ( 0 内の数字) )

\begin{tabular}{|c|c|c|c|}
\hline 方向 & 部材 & 寸法 $[\mathrm{cm}]$ & 要素分割 \\
\hline 水平 & $\begin{array}{c}\text { 柱幅 } \\
\text { スパン内法 }\end{array}$ & $\begin{array}{r}55.0 \\
545.0\end{array}$ & $\begin{array}{r}9.00 \times(1), 9.25 \times(4), 9.00 \times(1) \\
18.00 \times(10,18.50 \times(10,18.00 \times(10)\end{array}$ \\
\hline 直 & $\begin{array}{c}\text { 基砥梁せい } \\
1 \sim 9 \text { 階梁せい } \\
1 \text { 階柱内法 } \\
2 \sim 9 \text { 階柱内法 }\end{array}$ & $\begin{array}{r}40.0 \\
75.0 \\
282.5 \\
285.0\end{array}$ & $\begin{array}{l}10.00 \times(4) \\
9.35 \times(2), 9.40 \times \text { (4), } 9.35 \times(2) \\
14.00 \times(5), 14.25 \times \text { (10), } 14.00 \times(5) \\
14.00 \times(5), 14.50 \times \text { (10) } 14.00 \times(5)\end{array}$ \\
\hline
\end{tabular}




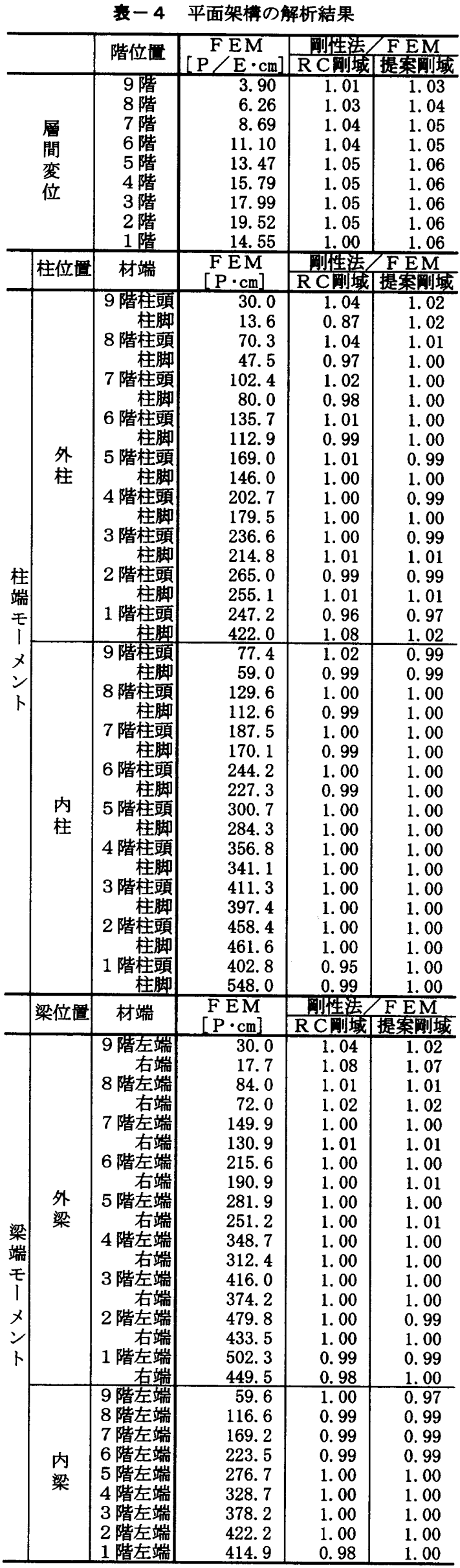

場合には比の值の変動が小さくなっている。なお、抽論 ${ }^{11}$ で弾性論 との比較あるいは要素分割数を变えて検討した結果によれば、本諭 で用いた要素分割で得られる F EM解析值の変位は正解より数\%小 さく算出されていると考えられる。このことを考虑すると、提案网 域を用いて得られた変位は極めて正解に近いものであると言えよう。

(2) 柱端モーメントについて

柱端モーメントについて見ると、R C 㣚域を取り入れた場合には 外柱の最上階柱脚で F EM值より小さく、同最下階柱㑢で大きくな っているが、提案剛域を取り入れた場合にはこれらの材端において も F EM値に近似した值となっており、提案棡域による改善が認め られる。

（3）梁端モーメントについて

梁端モーメントについて見ると、いずれの䣓域を取り入れた場合 にも外梁の最上階右端で F EM值より大きくなっているが、その他 はいずれもFEM值に概ね近似した值となっている。

以上のことから、本論で提案する㣚域長さ推定式は実用に十分耐 え得るものと考える。

\section{5. まとめ}

本論では、まず、断面寸法を種々に変化させた、柱梁からなる部 材模型（通常存在すると考えられる筑囲のもの）を三次元有限要菜 法解析し、その結果に基ついて岡域長さを求めた。更に、部材せい $D_{c}$ 、部材幅 $t_{c}$ 、直交部材せい $D_{b}$ 、直交部材幅 $\mathrm{t}_{\mathrm{b}}$ を変数として、そ れらの剛域長さを統計的に処理し、剛域算定式を提示した。

次に、その㣚域を適用した平面架柈モデルの線材置换による解析 值と同モデルの二次元有限要素法解析值の比較により、䣓域算定式 の有用性について検討した。それらの結果をまとめると以下の通り である。

（1）既往の剛域長さ算定式（RC剛域）では、 $D_{c} 、 D_{b}$ のみにd って剛城長さを求めるとしているが、それらの他に $\mathrm{t}_{\mathrm{c}} 、 \mathrm{t}_{\mathrm{b}}$ も剛軽 長さに大きく影鄆する。

（2）R C剛域では直交部材が部材の両侧にあっても、片側にあっ ても同值となるが、直交部材が両側にあるか、片側のみかによって 棡城長さは大きく変わる。

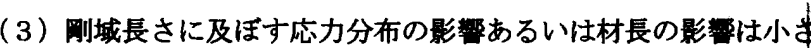
い。

（4）本諭の提案式による剛域を取り入れた平面架櫢モデルの解柿 結果は、R C 剮域を取り入れたそれよりも、二次元有限要素法解析 結果に対応し、本論の提案式が十分有用であると確認された。

\section{考考文城}

1）北川激，大筑和夫，鉿木邦康 : たわみ角法及ひ剛性法による水平力を受け る鉄筇コンクリート平面ラーメン解析の精度について, 日本建筑学会楼连 系論文集，N No.524，pp. $73 \sim 80 ， 1999.10$

2）日本建筑学会 : 鉄筋コンクリート棈造計算規等・同解䂱，1999

3）奥田勇 : 架椿材の定数について，東京大学卒莱論文，1927

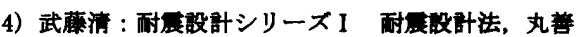

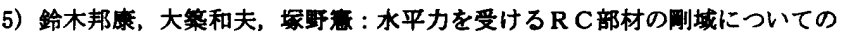
検討（その 1 有限要絜法解析に基つく䦌城について），日本建築学会大 会学術檴演梗概集 C2, pp. 831 832, 1995.8

6）大権和夫，鈴木邦康，椒野由共子 : 有限要来法解析による水平力を受ける R C 部材の制城について, 日本建篦学会北海道支部研究報告集, $\mathrm{Na} 68$, pp. $193 \sim 196,1995.3$

[2000年 4 月20日原稿受理 2000年 7 月26日採用決定］ 